\title{
Makten, härligheten och kärleken
}

\section{THOMAS JOHANSSON}

Under senare år har man diskuterat hur män på olika sätt lyckats vidmakthailla och försvara sina maktpositioner, trots ett långtgående och delvis mycket framgångsrikt arbete för jämställdhet mellan könen. I denna diskussion har begreppet manlig hegemoni figurerat flitigt. I den här artikeln kommer detta begrepp att diskuteras och utvecklas. En delvis reviderad modell kommer att presenteras. Med denna som utgångspunkt diskuteras vilka möjligheter det finns att involvera män i en aktiv kamp för jämställdhet.

\section{Maskulinitet - nostalgisk längtan eller ny manlighet?}

Den framväxande mansforskningen har inneburit ett ökat fokus på mäns sociala och kulturella förhållanden och den har framför allt lett till en ökad problematisering av det manliga. Vi ställer oss numera frågan: vad är en man? Som mansforskare balanserar man fram mellan att å ena sidan vilja ge rättvisa åt mäns röster, upplevelser, uppfattningar och så vidare, och att å andra sidan sätta in

Thomas Johansson, docent i sociologi, leg. psyko$\log$, leg. psykoterapeut. Författare till bl.a. Den skulpterade kroppen (Carlssons förlag 1998) och Socialpsykologi. Moderna teorier och perspektiv. (Studentlitteratur 1999). allt detta i ett maktperspektiv, för att kritiskt granska och uttala sig om mäns "faktiska« vilja till förändring och jämlikhet.

För att kunna hantera dessa delikata frågor måste vi som mansforskare utveckla teoretiska redskap som kan användas för att analysera konstruktionen av manlighet både generellt och mer specifikt i relation till frågan om makt och förändring. I den här artikeln avser jag att diskutera en numera välkänd maktmodell - Robert Connells analys av hegemonisk maskulinitet. Min avsikt är att presentera, komplettera och förhoppningsvis bidra till att utveckla denna modell. Inledningsvis diskuteras hur vi kan närma oss frågan om jämlikhet på olika analytiska nivåer, därefter vidtar en diskussion av 
Connells modell och allt detta utmynnar i frågan: Vad vill männen egentligen?

\section{Den jämlika ojämlikheten}

När vi mot slutet av 1900-talet summerar upp hur långt vi kommit när det gäller jämställdhet mellan könen finns det all anledning att på en och samma gång vara både optimistisk och pessimistisk. $\AA$ ena sidan har det ju hänt väldigt mycket. Ända fram till år 1864 hade den svenske mannen rätt att aga sin hustru och en bra bit in på 1900-talet saknade kvinnor demokratiska rättigheter. Och först år 1921 fick den svenska kvinnan rösträtt. Under 1980- och 90-talet har å ena sidan ett antal lagar stiftats för att befrämja kvinnors rättigheter. $̊$ andra sidan finns det idag fortfarande stora ekonomiska, sociala och kulturella skillnader mellan män och kvinnor. Kvinnor har i allmänhet huvudansvaret för hem och barn, ofta lägre löner än männen och helt enkelt mindre makt.

Men även om det fortfarande är möjligt att tala om en manlig hegemoni, det vill säga om att män i allmänhet har mer makt än kvinnor i samhället, finns det samtidigt mycket som tyder på att denna hegemoni har blivit allt mer ostabil. Den manliga maktutövningen står sällan oemotsagd, det riktas ständigt en kritik mot alla former av manlig dominans i samhället.

I diskussionen om jämställdhet tenderar man ofta att blanda samman olika strukturella nivåer. De som identifierar starka förändringar av könsidentiteterna och som tycker att samhället utvecklas i en pluralistisk snarare än ojämlik riktning tenderar att stirra sig blinda på den kulturella nivån, medan de som konstaterar att det fortfaran- de är status quo i stor utsträckning fokuserar den ekonomiska och sociala nivån.

I kvinnomaktutredningens slutbetänkande konstaterar man att det fortfarande är så att de svenska företagen styrs av män. Endast 3 procent av ledamöterna i de börsnoterade företagens styrelser är kvinnor och bland 229 börsnoterade företag finns det endast en kvinnlig VD. ${ }^{1}$ Det är alltså män som är innehavare av den ekonomiska makten. Arbetsmarknaden är också i stor utsträckning könssegregerad. Även om mycket har förändrats återfinns fortfarande ett könsspecifikt mönster där män har högre inkomster och bättre avancemangsmöjligheter än kvinnor. Kvinnornas genomsnittliga timlön är cirka 80 procent av männens och ju högre upp i hierarkierna man når desto färre kvinnor återfinner man. Trots dessa dystra siffror kan man även konstatera att kvinnorna i allt större utsträckning tar sig in på arbetsmarknaden och erövrar offentligheten.

På en social nivåblir "könskampen" extra tydlig. Skilsmässorna ökar i allt snabbare takt. Ju mer ekonomiskt oberoende kvinnor blir desto mer ökar förhandlandet om hur vardagslivet skall organiseras. När dessa förhandlingar bryter samman resulterar det ofta i separationer. Då kvinnors positioner på arbetsmarknaden blir bättre ökar också deras möjligheter att bryta sig ur destruktiva förhållanden. I kvinnomaktutredningen kan man läsa följande:

Kvinnors ekonomiska maktresurser har ökat och deras s.k. fall-back position, dvs. alternativen utanför äktenskapet, har förbättrats avsevärt. Det faktum att det pågår förhandlingar

1 SOU 1998:6. 
i familjerna om vem som skall städa och vem som skall byta blöjor är ett tydligt tecken på att kvinnor stärkt sina positioner. Ju mer ekonomiskt oberoende kvinnor blir av män, desto mer ökar förhandlandet och desto fler arbetsuppgifter förhandlar man om. ${ }^{2}$

Även om det pågår drastiska förändringar av vardagslivet är det dock fortfarande så att kvinnor i högre utsträckning än män ansvarar för och organiserar hemarbetet, men samtidigt har den traditionella könsuppdelningen blivit allt mer ohållbar.

På en kulturell nivå kan man urskilja ett flöde av massmediala bilder som reproducerar en rad olika föreställningar om det manliga och det kvinnliga. Här återfinner man dels en tendens till ett förstärkande av könspolariseringen, där män framställs som tuffa, hårda och obevekliga, medan kvinnor intar en mer klassiskt passiv position, dels finns det starka inslag av ifrågasättanden av polariserade könsföreställningar. Män och manliga kroppar estetiseras och den vackre ynglingen får ett allt större utrymme i medierna och på reklampelarna, medan kvinnor förekommer i actionfilmer och framställs som machoideal. Dessa motstridiga tendenser skapar också ett allt mer ironiskt förhållningssätt till representationen av kön.

På en subjektiv nivå kan man iaktta en ökad reflexivitet. De ökade kunskaperna om de sociologiska och historiska förutsättningarna för reproduktionen av kön bidrar till att relativisera det manliga och det kvinnliga. Få människor accepterar idag helt och hållet det biologiska argumentet, dvs. att män och kvinnor skulle ha olika biologis-

2 Ibid:70. ka förutsättningar när det gäller utbildning, karriär och så vidare. Det ökade ifrågasättandet av polariserade könskategorier skapar ett allt starkare tryck på framför allt män att överge sina maktpositioner. Så länge denna utveckling i första hand uppfattas som ett hot mot vissa privilegier kommer män säkerligen att fortsätta att försvara sina maktpositioner, men när de blir medvetna om och börjar sträva efter att ta del av de vinster som genereras via denna utveckling kommer mycket att förändras.

När vi närmar oss frågan om jämlikhet bör vi försöka undersöka relationen mellan de olika strukturella nivåer som berörts ovan. Den manliga hegemonin är ifrågasatt, men den är fortfarande starkt förankrad i vissa samhälleliga sektorer. Den sociala och kulturella reproduktionen bidrar också delvis till att befästa vissa klassiska könsskillnader. Samtidigt är det viktigt att ta fasta på de förändringsprocesser som på lång sikt kommer att leda till en försvagning och till en eventuell upplösning av den manliga dominansen.

För att vi skall kunna analysera dessa förändringsprocesser och ta reda på vilka konsekvenser de får för den samhälleliga makthierarkin är det nödvändigt att utveckla tankar och teorier om manlighet och jämställdhet. I den följande texten har jag valt att uteslutande fokusera den manliga hierarkin. Utifrån en diskussion och utveckling av den australiensiske mansforskaren Bob Connells maktmodell behandlas således förändringar i dagens manlighet. ${ }^{3}$

3 I den fortsatta framställningen utgår vi från Connells maktmodell (Connell 1995). 


\section{Makt och manlighet}

I industrisamhället var det männen som garanterade familjen en inkomst och därmed överlevnad. Samtidigt som männen för att kunna försörja sina familjer gav sig ut i arbetslivet, tog kvinnorna över kontrollen över den privata sfären. ${ }^{4}$ Denna polariserade rollfördelning - där männen förankrade sina identiteter i den offentliga och kvinnorna i den privata sfären - ifrågasattes först på allvar när kvinnorna började yrkesarbeta. I det samtida samhället har männen förlorat sin ensamrätt på att förankra identiteten i yrkeslivet och idag pågår det en betydlig omvandling av relationen mellan könen och mellan den privata och offentliga sfären. Trots dessa förändringar är det dock fortfarande i högre utsträckning män än kvinnor som intar olika maktpositioner i samhället. Även om allt fler kvinnor träder in i ledande positioner och får tillträde till makten är det fortfarande inom ramen för klassiskt manliga sociala institutioner och organisationer som detta sker.

Att män i högre utsträckning än kvinnor intar maktpositioner i samhället är givetvis inte detsamma som att alla män har samma tillgång till makt. Enligt Connell kan man urskilja en manlig hierarki där män intar olika positioner. Han skiljer mellan tre olika positioner inom den manliga hierarkin: hegemonisk-dominant, delaktig och underordnad. Denna hierarki bör emellertid alltid analyseras i relation till en allmän samhällelig makthierarki - baserad på sådana fakto-

4 Övergången från ett patriarkat till ett samhällssystem som placerade modern som huvudansvarig för barnen har analyserats av Gillis (1996), och många andra historiker. rer som klass, status, etnicitet och så vidare - där män kan inta en mer eller mindre central eller marginaliserad position. Här kan man sedan tänka sig olika manliga positioner och olika maskuliniteter.

Connell menar att det är en liten minoritet av alla män som totalt förkroppsligar den hegemoniska positionen. Här inkluderas bland annat de män som har ledande positioner inom näringsliv och den statliga sektorn. Dessa män uppfyller många av kriterierna på en dominerande manlighet; de har ekonomisk såväl som kulturell makt i den bemärkelsen att de påverkar hur samhället utformas. De har följaktligen ett starkt inflytande över vilka värden som upphöjs till normativa riktlinjer för människors liv. Men de flesta män befinner sig inte i en sådan nära relation till makten i samhället, utan har ett mer problematiskt förhållande till denna hegemoniska position.

Den delaktiga manligheten är komplex och präglas både av en närhet till den hegemoniska positionen - vad Connell ytterst betraktar som en form av allians med makten, ett medlöperi - och av ständiga kompromisser och förhandlingar med de kvinnor dessa män delar sitt vardagsliv. Här finns det en poäng i att utvidga Connells modell och skilja mellan delaktighet (i bemärkelsen delaktighet i maktutövning och könsförtryck) och förhandling. I vardagslivet måste män ständigt förhandla med kvinnor och med andra män. Detta leder till förändringar i konstruktionen av det manliga. Samtidigt finns det ofta möjligheter för män att så att säga "falla tillbaka» mot den hegemoniska maskuliniteten; att återigen bli delaktiga i reproduktionen av denna maktposition. 


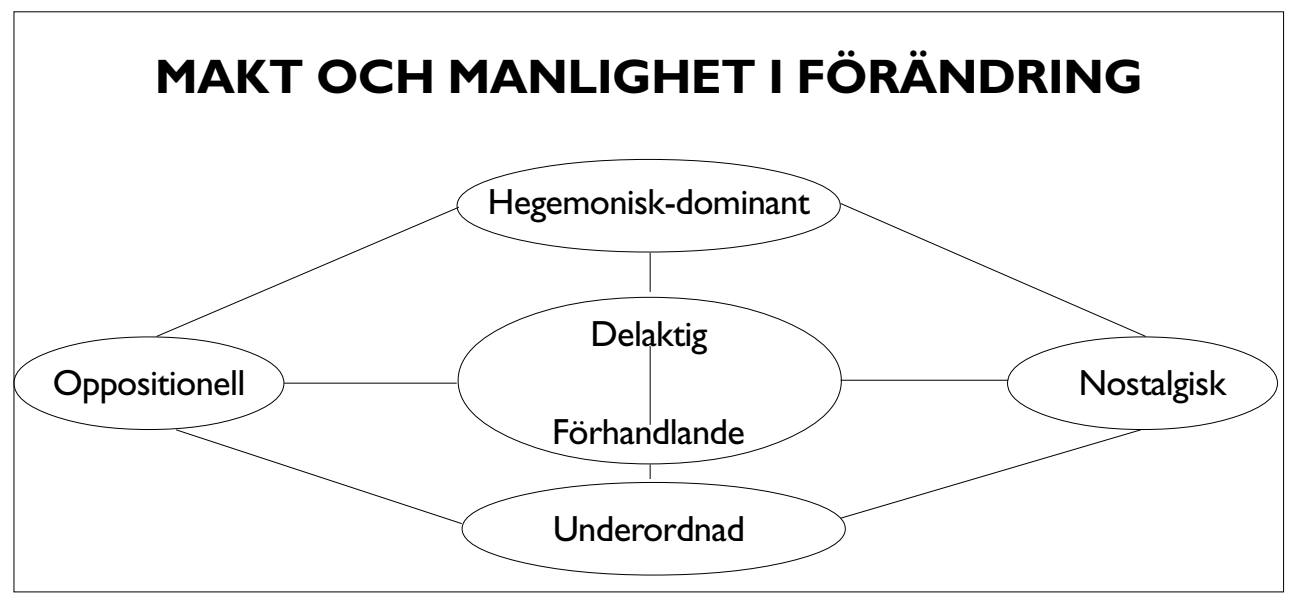

Eftersom det fortfarande är så att många män har en högre inkomst än de kvinnor de delar sina liv med finns det en stor risk för att traditionella mönster förstärks snarare än raseras. De flesta män pendlar mellan delaktighet och förhandling, vilket innebär att det gradvis äger rum förändringar i relationen mellan könen och att den manliga hegemonin successivt urholkas.

Även om det blivit allt mer tillåtet för män att estetisera sina kroppar och att vara "mjuka» och barnorienterade, finns det fortfarande tabun som reglerar gränserna mellan det manliga och det kvinnliga. De män som på ett eller annat sätt överskrider dessa gränser betraktas ofta som homosexuella och "feminina" - det vill säga som underordnade andra män. Ju mer tillåtet det blir att experimentera med sådana tabun och gränser, desto otydligare blir gränsen mellan förhandling och underordning.

Den manliga hierarki som Connell beskriver bör kompletteras med ytterligare två typer: den oppositionella och den nostalgiska manligheten. Liksom den förhandlande präglas den oppositionella positionen av ett nära samarbete med kvinnor och en kritisk inställning till de dominerande manliga strukturerna i samhället. ${ }^{5}$ Dessutom utgör den en utgångspunkt för att formulera en plattform för en symbolisk och reell kamp mot den hegemoniska manligheten. Den nostalgiska positionen kännetecknas istället av en längtan tillbaka till en urmanlighet; till en mytisk tid då män inte grubblade över sin identitet utan hade (eller i varje fall upplevde sig ha) en stark inre känsla av maskulinitet. Denna typ av regressiv rörelse har bland annat tagit sig uttryck i form av den mytopoetiska tolkningen av vår tids manlighet, men även i mansrörelser av mer fundamentalistiskt slag, som till exempel den kristna rörelsen Promise keepers. Men den kan även slå över i en stark antifeminism och i sin förlängning i psykologiskt och fysiskt våld mot kvinnor.

Den manliga hierarki som Connell skisserar bör givetvis sättas i relation till den allmänna kampen för jämställdhet i samhället. Många män pendlar fortfarande mellan del-

5 Se Stuart Hall (1998) för en maktmodell som till stora delar sammanfaller med den som Connell utvecklat. 
aktighet och förhandling och det finns en stark beroenderelation till den dominerande manligheten. Detta innebär att relationen mellan de delaktiga, hegemoniska och nostalgiska positionerna fortfarande väger tyngre än relationen mellan de förhandlande, underordnade och oppositionella positionerna. Det är fortfarande i första hand kvinnor som driver kampen för jämställdhet; som engagerar sig på konferenser, arbetar för lagändringar, uppmärksammar könsförtryck och så vidare.

I ett samhälle som präglas av stora strukturella förändringar, och av en marginalisering av de män som tidigare förankrade sina identiteter i klassiskt manliga yrken, påverkas och omstruktureras givetvis den manliga hierarkin. Här öppnas en möjlighet för kvinnor att träda in som aktörer och det ställs därmed större krav på män att förändra sig och att anpassa sig till dessa förändringar. En sådan omstrukturering behöver inte nödvändigtvis hota den manliga hegemonin. Även om den leder till en förändrad syn på det manliga och till framväxten av en mer flexibel manlighet, innebär inte detta automatiskt att den manliga hegemonin totalt eroderar. När allt fler kvinnor skaffar sig höga maktpositioner i samhället förändras också förutsättningarna för att diskutera relationen mellan kön och makt. Vad som är "manligt« respektive »kvinnligt« är inte längre lika självklart.

De män som marginaliseras kan antingen svara med att förändra sin manlighet eller med att krampaktigt försvara sina privilegier som män. På så sätt kan ett hot mot den manliga hierarkin generera ett antal olika motstrategier och försök att återigen ontologisera manligheten. En marginaliserings- process kan således leda till ett förstärkande av den manliga hegemonin. Det är inte heller ovanligt att marginaliserade män tenderar att ge uttryck för en mycket rigid och traditionell syn på kön och jämlikhet. ${ }^{6}$ En fortsatt strävan efter jämlikhet mellan könen leder till ett gradvis uppluckrande av tidigare identitetsmarkörer. I bästa fall leder denna process till att män och kvinnor utvecklar en förmåga till gränsöverskridande och på så sätt motverkar traditionella könsroller. Men hotet mot den ontologiska trygghet som tidigare genererats av fasta roller och en klar arbetsfördelning kan också bidra till att förstärka könspolariseringen. Detta kan bland annat ske i form av re-ritualiseringar av det manliga; "gamla» beprövade ritualer återanvänds för att åter stärka den manliga dominansen. Den mest primitiva varianten av detta tar sig uttryck i sexuellt våld och $\mathrm{i}$ ett förringande av kvinnor? ${ }^{7}$

\section{Ritualiseringar och kompromissbildningar}

I början av Fever Pitch beskriver Nick Hornby hur hans fader ivrigt försökte få honom att följa med på fotboll när han var i 10-års åldern, men utan att lyckas speciellt bra. Det var först när familjen splittrades och han allt mer sällan träffade sin fader, förutom vid de enskilda tillfällen då de gick på djurparken, som han plötsligt tappade intresset för allt som inte kretsade kring fot-

6 Här finns ett antal empiriska analyser, som i och för sig inte utgår från ett maskulinitetsperspektiv, som kan användas som utgångspunkt för denna typ av resonemang (se bland annat Willis 1977/1983).

7 För en analys av detta, se Månsson (1998). 
bollsmatcherna. Det var då han blev en äkta fotbollssupporter. På så sätt utvecklade också far och son ett gemensamt identitetsprojekt. Denna ritualisering av det manliga innefattar en rad ingredienser i form av lukter, synintryck och så vidare. Hornby beskriver detta på följande sätt:

But I do have other, more reliable, and probably more meaningful memories. I remember the overwhelming maleness of it all - cigar and pipe smoke, foul language (words I had heard before, but not from adults, not at that volume), and only years later did it occur to me that this was bound to have an effect on a boy who lived with his mother and his sister; and I remember looking at the crowd more than at the players. ${ }^{8}$

Vissa fritidsaktiviteter och yrken lämpar sig helt klart bättre än andra för ritualiseringar av manlighet. Formeln: sport, snabba bilar och "snygga brudar" fungerar fortfarande som en identitetsmarkör för många män. Samtidigt blir det idag allt svårare att på ett relativt okomplicerat sätt förankra den manliga identiteten i olika typer av ngubbighet». Många klassiska manliga arbetaryrken har försvunnit och den traditionella och hegemoniska manligheten är utsatt för en stark kritik av kvinnor såväl som av män. Denna opposition mot den manliga hegemonin leder dock till motstrategier i form av re-ritualiseringar av det manliga. Den form av backlash som Faludi beskrivit bör delvis förstås som ett "svar» på faktiska förändringar av relationen mellan könen och som en del av den symboliska kamp som handlar om hur man skall definiera det manliga respektive det kvinnliga.

8 Hornby (1992:19).
Idag kan man också som tidigare nämnts urskilja en nostalgisk längtan efter en form av urmanlighet - en "naturlig manlighet». Denna nostalgi kan ta sig uttryck i olika försök att ontologisera manligheten. Robert Blys mytopoetiska mansrörelse kännetecknas i hög utsträckning av en sådan strävan efter att återskapa symboliska gemenskaper och efter att finna den wäkta inre manligheten«. Detta behöver i och för sig inte bara yttra sig i ett sökande efter en urmanlighet, utan den kan även ta sig uttryck i ett förstärkande av grabbigheten; ett slags bejakande av formeln: sport, snabba bilar och snygga brudar.

De re-ritualiseringar som uppträder i dagens Sverige bör tolkas som motstrategier och som försök att "vrida klockan tillbaka». Ofta försvarar sig tidningsredaktörer och andra manliga kulturförmedlare med att beskylla feminister och pro-feministiska män för att de försöker skuldbelägga män som ägnar sig åt typiska "manliga» aktiviteter. Denna typ av argumentation går ut på att påvisa det ofarliga och harmlösa i återuppväckandet av klassiskt manliga ritualer. Genom att använda skuldargumentet och ironi lyckas man "vinna terräng" för olika typer av försvar av den hegemoniska manligheten. På så sätt lyckas chefredaktörerna för sådana tidningar som Slitz och Cafe, med glimten i ögat, bidra till en betydande re-ritualisering av en klassisk form av dominant maskulinitet. Även om de flesta män inte förkroppsligar denna typ av dominant manlighet utgör olika former av re-ritualiseringar en del av kampen om vem som skall definiera det manliga respektive det kvinnliga.

Men samtidigt som vi kan se tecken på att män försvarar den manliga bastionen, 
förekommer också andra och mer hoppfulla tendenser. När man talar om vardagsmannen används ofta uttrycket "I-princip-mannen«. Denna formulering fångar något av den ambivalens som karakteriserar dagens manlighet, men samtidigt tenderar man att underskatta de faktiska förändringar som äger rum i vardagslivet. "I-princip» är en attityd, det vill säga den avser de män som tenderar att säga: »Jag skulle i och för sig vilja ta ansvar för en större del av hushållsarbetet, men nu är det ju så att jag istället har ansvar för att underhålla bilen och vattna i trädgården«. Jag skulle dock vilja påstå att den ambivalens som karakteriserar dagens manlighet tränger djupare in i porerna på männen än vad sådana attityder ofta förespeglar.

Istället för att tala om "I-princip-mannen« skulle jag vilja föra fram »kompromissmanligheten«. Konstruktionen av dagens manlighet präglas av motstridigheter. Dels vill många män stanna hemma hos sina barn och leva i jämlika relationer med de kvinnor de delar sina liv med. Samtidigt är fortfarande stora delar av den manliga identiteten starkt förankrad i arbetssfären och i de former av kompetenser som utvecklas inom denna sfär. Män har lättare för att formulera sina identitetsanspråk i den offentliga än i den privata sfären. Trots detta försöker många män utveckla en mer nyanserad manlighet. De försöker sammanfoga de impulser och önskningar som härrör från den grundläggande socialisationen till man, som fortfarande är relativt traditionell, med de krav på flexibilitet och förändring som ställs på dagens manlighet. Vardagsmannen präglas av en förhandlande manlighet, som dels måste sättas i relation till den delaktiga och hegemoniska manligheten, dels till kvinnors ökade krav på jämställdhet och lika värde. Om man skall studera och försöka förstå dagens manliga uttryck måste man därför fokusera de motstridiga tendenser som inryms i konstruktionen av denna manlighet.

\section{Vad vill männen?}

En del av svårigheterna med att utveckla den nya manligheten kan lokaliseras till mäns svårigheter att artikulera denna förändring. Mansforskningen handlar också ofta om mäns problematiska förhållande till sitt känsloliv och om svårigheterna att verbalisera och tydliggöra hur en framtida manlighet skulle kunna se ut. ${ }^{9}$ Det saknas också idag i stor utsträckning kollektiva försök att utveckla strategier för hur en ny manlighet skall kunna formuleras och genomföras. Detta innebär dock inte att män inte vill förändras. I vardagslivet pågår det ständiga försök till förändringar av det manliga.

Vid de tillfällen då män skapar ett kollektivt utrymme för att diskutera de problem och svårigheter de stöter på $i$ vardagslivet finns det ofta en risk att dessa formationer förblir isolerade öar. Inte så sällan används sådana kollektiva plattformer för att artikulera ett missnöje med de kvinnor som männen anser har berövat dem kontakten med barnen. Risken är att man istället för att inse att strävan efter jämlikhet utgör enda möjligheten för män att vinna tillbaka kontakten med barnen och att skapa förutsätt-

9 Se bland annat Victor Seidler (1994) för en diskussion om mäns tystnad. 
ningar för fungerande parrelationer vänder sig mot denna strävan och kamp, och istället ropar efter mer traditionella könsroller.

Så länge männen inte engagerar sig mer aktivt i kampen för jämställdhet kommer det att vara kvinnorna som tar initiativet till att diskutera och formulera det nya och mer jämställda samhället. Det finns dock en risk för att många män inte kommer att känna igen sig i och vilja delta i byggandet av denna vision. På så sätt förstärks polariseringen mellan könen snarare än försvagas. Mäns frånvaro och tystnad kan tolkas som ett bifall till de förändringar som äger rum, och så kanske också är fallet, men det finns en risk för att tystnaden får en aggressiv karaktär. Förlusten av makt kan då leda till desperata försök att återupprätta Faderns lag.

I mäns tystnad kan man läsa in ett masochistiskt uthärdande av attackerna mot självkänslan och manligheten. En sådan process kan betraktas som nödvändig för att man sedan återigen skall kunna återupprätta det manliga. Detta är ett väl känt tema i många Westernfilmer, till exempel. Idag finns det vissa män som känner sig hotade av kvinnornas frammarsch. Den re-ritualisering som förekommer idag är också ett tydligt tecken på hur män försöker att återerövra en exklusivt manlig sfär. Genom att odla en mytologi kring det manliga skapas det förutsättningar för en ontologisering av en klassiskt manlig och dominant position. Mäns svårigheter att verbalisera och symbolisera sina strävanden efter jämlikhet och en förändrad manlighet resulterar då i att de progressiva männen drivs tillbaka till fördel för de män som vill upphöja en manlig mytologisk värld till sanningen. En sådan strategi kan endast bekämpas genom att man konsekvent raserar grunden för ett sådant mytologiserande av manligheten. Och här kan vi ta hjälp Judith Butler.

\section{Judith Butler som mansforskare}

När Barthes beskriver skapandet av mytologier talar han om en andra ordningens språkligt system. Myterna skapas via användandet och reartikuleringen av redan befintliga språkliga konstruktioner. Det formuleras med andra ord specifika kopplingar mellan det betecknande och det betecknade och därmed vissa bestämda symboler. ${ }^{10}$ Konstruktionen av könsidentiteter är till stor del en fråga om hur olika saker betecknas och om vilka skillnader som upprättas via språket. Genom en omfattande mytbildning kring det manliga och det kvinnliga har vårt sätt att betrakta dessa kategorier naturaliserats och blivit fastlåst i en relativt traditionell och polariserad syn på kön.

Ett sätt att formulera nya könsidentiteter är att bryta upp de myter som konstruerats och att skapa nya och mer "jämlika» myter. Genom att använda ironin som vapen och visa på det orimliga i könskonstruktionen kan man bidra till en förändringsprocess. Detta är också just vad Judith Butler sysslar med i sina olika framställningar av kön.

Kön förkroppsligas och naturaliseras genom människors handlingar. Via tysta kollektiva överenskommelser och en ständig dramatisering av kön skapas och förändras vårt sätt att betrakta det manliga och det kvinnliga. Enligt Butler blir detta "spel» först riktigt synligt när gränserna mellan

10 Barthes (1957/1989). 
det manliga och det kvinnliga hotas. Hon hämtar själv sina exempel från transvestiter och andra former av könsuppluckringar, men man kan lika gärna använda kvinnliga bodybuilders som exempel på denna typ av hot mot människors ofta grundmurade uppfattningar av kön. Butler leker med tanken att våra könsidentiteter är helt och hållet konstruerade. Hon skriver:

Because there is neither an "essence" that gender expresses or externalizes nor an objective ideal to which gender aspires, and because gender is not a fact, the various acts of gender create the idea of gender, and without those acts, there would be no gender at all. Gender is, thus, a construction that regularly conceals its genesis; the tacit collective agreement to perform, produce, and sustain discrete and polar genders as cultural fictions is obscured by the credibility of those productions - and the punishments that attend not agreeing to believe in them; the construction "compels" our belief in its necessity and naturalness. The historical possibilities materialized through various corporeal styles are nothing other than those punitively regulated cultural fictions alternately embodied and deflected under duress. ${ }^{11}$

Hur kan man då använda Butler i studier av manlighet? Genom att hon ifrågasätter hela tanken på fasta könskategorier skapas det möjligheter att utveckla en ny typ av mytologi som på ett raffinierat sätt tillåter det manliga och det kvinnliga att blandas, mixas och eventuellt också upplösas för att ta sig nya konturer - bortom rigida uppdelningar och biologismer. En sådan radikal strategi tvingar oss att ständigt ifrågasätta hur vi drar våra könsgränser.

Via ironin och det ständiga utforskandet

11 Butler (1990:140). av subtila gränszoner lyckas Butler rikta uppmärksamheten mot möjligheterna att bryta upp de relativt fasta gränsdragningar som ligger till grund för det ojämlika förhållandet mellan könen. På så sätt skapar hon förutsättningarna för en kritik av den mytologiska världsbild som färgar vår syn på kön. Ironin och bejakandet av gränsöverskridanden bidrar till att relativisera de könskategorier som ligger till grund för reproduktionen av ojämlika relationer mellan män och kvinnor. Samtidigt används ironin för att reritualisera det manliga; så den är ett tveeggat vapen $i$ kampen för jämställdhet.

För att de olika strategier och den kritik som utvecklats för att underminera den hegemoniska maskuliniteten skall få avsedd verkan måste detta arbete kombineras med medvetna försök att formulera väsentliga frågor om jämställdhet och manlighet samt med försök att aktivera män i mer kollektiva former. Det räcker alltså inte att bara ifrågasätta den manliga hierarkin, utan det är även nödvändigt att formulera jämställdhetsfrågor ur ett perspektiv som tar hänsyn till och utgår från mäns upplevelser och behov av förändring. Först måste män fråga sig vad de har att vinna på ett jämställt samhälle och det är först när det hittar några svar på denna fråga som de kommer att aktivera sig i kampen för förändring. Dessa kulturella strategier måste givetvis kombineras med försök att ändra själva det ekonomiska och sociala fundament som bidrar till att cementera polariserade positioner och ojämlikhet. För att återknyta till inledningen och distinktionen mellan olika analytiska nivåer - kampen måste föras på alla nivåer, samtidigt och med full kraft. Här behövs männen? 


\section{Summary \\ Power, glory and love}

This article deals with the concept of hegemonic masculinity. The author suggests certain extensions of the original model created by Robert W. Connell. The concepts of nostalgic and oppositional masculinity are introduced. This conceptual discussion is thereafter related to the question: "Do men really want to participate in the struggle for equality?" The author suggests that we have to develop a more radical view of men and masculinity, in order to initiate a serious men's movement in a Swedish context.

\section{Litteratur}

Barthes, R (1957/1989) Mythologies. London: Paladin.

Butler, J (1990) Gender Trouble. Feminism and the Subversion of Identity. New York: Routledge. Connell, R.W (1995) Masculinities. Cambridge: Polity Press.

Gillis, J.R (1996) A World of their own making. Myth, Ritual and the Quest for Family Values. Cambridge: Harvard University Press.

Hall, S (1998) »Kodning och avkodning». I Johansson, T, Sernhede, O och Trondman, M(red.) Samtidskultur. Karaoke, karnevaler och kultu- rella koder.Nora: Nya Doxa.

Hornby, N (1992) Fever Pitch.

Månsson, S-A (1998) „Gaining or Losing? Aspects on Menıs Violence and Sexuality". Paper presented at the $4^{\text {th }}$ International meeting on penal Sciences, November 17-20, 1998.

Seidler, V (1994) Unreasonable Men. London: Sage. SOU 1998:6, Slutbetänkandet från kvinnomaktutredningen.

Willis, P (1977/1983) Fostran till lönearbete. Göteborg: Röda bokförlaget. 